\title{
Integrated Broomrape (Orobanche crenata Forsk.) Control in Faba Bean (Vicia faba L.) with Nitrogen Fertilizer, Intercropping and Herbicides
}

\author{
A.M. Ghalwash, H.S. Gharib" and Azza E. Khaffagy \\ Weed Res. Cent. Lab., Agric. Res. Center, Giza and *Agronomy \\ Dept., Fac. Agric., Kafrelshiekh Univ., Kafrelshiekh Egypt.
}

7 WO FIELD experiments were carried out at the farm of Sakha Agricultural Research Station, Kafrelshiekh, Egypt, during 2010-2011 and 2011-2012 faba bean growing seasons (Latitude $30^{\circ}$ $48^{`} \mathrm{~N}$, Longitude $\left.31^{\circ} 35^{`} \mathrm{E}\right)$. The trials studied integrated broomrape (Orobanche crenata Forsk.) control in faba bean cv. Giza 843 with nitrogen fertilizer, intercropping faba bean (Vicia faba L.) with oat (Avena sativa $\mathrm{L}$.) or fenugreek (Trigonella foenum-graecum $\mathrm{L}$.) and herbicides. Herbicide treatments were: 1- Untreated, 2- Glyphosate $(48 \% \mathrm{WSC})$ at $36 \mathrm{~g}$ a.i./fed., (fed $=$ feddan $=0.42$ hectare),(once)., 3 Glyphosate (48\% WSC) at $36 \mathrm{~g}$ a.i./fed. (twice)., 4- Imazapic (10\% $\mathrm{EC})$ at $20 \mathrm{~g}$ a.i./fed. (once), 5- Imazapic (10\% EC) at $20 \mathrm{~g}$ a.i./fed. (twice). Sub-plots were assigned to faba bean (sole crop), intercropping (faba+ oats), (faba+ fenugreek) and nitrogen fertilizer with ammonium nitrate $\left(\mathrm{NH}_{4} \mathrm{NO}_{3}\right)$.

The two broomrape control herbicides substantially suppressed number and dry weight of broomrape spikes $/ \mathrm{m}^{2}$ compared with untreated in both seasons. Foliar spray of Imazapic and Glyphosate twice on faba bean recorded a less number and dry weight of broomrape spikes $/ \mathrm{m}^{2}$ than its spray one time. Spikes number and dry weight of broomrape parasite weed $/ \mathrm{m}^{2}$ were significantly decrease in faba bean intercropped with fenugreek and oat or fertilized with nitrogen compared with sole faba bean in both seasons. Intercropping faba bean with fenugreek (Trigonella foenum-graecum L.) recorded the lowest number and dry weight of broomrape spikes $/ \mathrm{m}^{2}$ followed by application of $\mathrm{N}$ fertilizer then oat in the two seasons. Foliar spray of Imazapic twice on faba bean intercropped with fenugreek recorded a less number and dry weight of broomrape spikes $/ \mathrm{m}^{2}$. There were no significant differences in spikes number and dry weight of broomrape weed $/ \mathrm{m}^{2}$ among application of fenugreek and oat or $\mathrm{NH}_{4} \mathrm{NO}_{3}$ with spraying Imazapic or Glyphosate twice in both seasons. The greatest reduction in number $(>82 \%)$ and dry weight (> 90\%) of broomrape spikes $/ \mathrm{m}^{2}$ were obtained by application of fenugreek along with Imazapic herbicides twice in both seasons.

Repeating foliar spray with either Imazapic or Glyphosate on faba bean plants resulted in a significant decrease in photosynthetic pigments (chlorophyll a, b and total chlorophyll) content in leaves compared with untreated treatment in both seasons. All photosynthetic pigments contents were significantly greater in leaves of faba bean fertilized by $\mathrm{N}$ fertilizer than in those of sole faba bean plants without $\mathrm{N}$ fertilizer or intercropped with fenugreek or oat in 
both seasons. Foliar spraying of the two herbicides once or twice on faba bean significantly increased plant height, number of branches and pods/plant, 100-seed weight, seed yield/plant, seed and biological yields/fed. of faba bean compared with untreated treatment in both seasons. Faba bean plants sprayed twice with of Imazapic herbicide significantly exceeded those sprayed once with Imazapic or Glyphosate herbicides in seed and biological yields as well as its attributes in both seasons. Faba been intercropped with fenugreek or fertilized with $\mathrm{NH}_{4} \mathrm{NO}_{3}$ produced significantly taller plants and greater seed and biological yields as well as its attributes than did sole faba bean without $\mathrm{N}$ fertilizer in both seasons. The combination of Imazapic herbicide twice and fenugreek recorded the highest seed yield, while sole faba bean plants without $\mathrm{N}$ fertilizer and untreated produced the lowest one in both seasons. It can be concluded that foliar spraying with Imazapic or Glyphosate twice on faba bean intercropped or fertilized with $\mathrm{NH}_{4} \mathrm{NO}_{3}$ could be recommended for optimum broomrape parasitic weed control and highest seed yield at Kafrelsheikh Governorate, Egypt.

Keywords: Intercropping, Nitrogen fertilizer, Broomrape, Fenugreek, Oat, Faba bean, Herbicide, Imazapic, Glyphosate

Crenate broomrape (Orobanche crenata Forsk.) is a root parasitic plant widely distributed in the Mediterranean region. It is a major constraint for the production of faba bean (Vicia faba L.) (Rubiales et al., 2002). Because their infestation occurs underground, they can cause enormous damage before their scapes appear above ground. As a consequence, efficient control is extremely difficult and infestation frequently results in a severe reduction of crop yields (Yoneyama et al., 2001). Many management practices have been tested against Orobanche including solarisation, herbicides, crop rotation, deep ploughing, intercropping, trap crops, resistant varieties, synthetic germination stimulants, animal manure, and inorganic nitrogenous synthetic fertilizers with limited success (Parker \& Riches, 1993; Nandula, 1998 and Elzein \& Kroschel, 2003). There is no one single method can give satisfactory control. Options for broomrape control are limited for most crops because of the difficulty of mechanical control and lack of reliable, selective herbicides. Integration of various control methods could lead to better control of broomrapes (Abu Irmaileh, 1994).

Some herbicides can be used successfully for broomrape (Orobanche crenata Forsk.) control in faba bean (Vicia faba L.). Imazapic, an imidazolinone herbicide used selectively PRE and POST, in peanut (Arachis hypogaea L.), soybean (Glycine $\max (\mathrm{L}$.) Merr.), and in non-crop areas, is usually applied at 50 to $70 \mathrm{~g}$ ai/ha. It is absorbed through the roots and foliage and rapidly translocated to growing points (Thomson, 1997). Imazapic has efficiently controlled Orobanche crenata and ensured a satisfactory equivalent yield in faba bean (Saffour et al., 2003; Ghalwash et al., 2008 and Kenapar, 2009). The application of Imazapic resulted in high level of broomrape (Orobanche

Egypt. J. Agron. 34, No. 2 (2012) 
crenata) control up to $84.0 \%$ and $86.0 \%$ in lentil (Al-Rahban et al., 2009). Glyphosate was the first promising herbicide developed for Orobanche crenata control in faba bean (Schmitt et al., 1979). Glyphosate applied twice post emergence at 60 to $80 \mathrm{~g}$ a.i./ha controlled broomrape in faba bean (Sauerborn et al., 1989, García-Torres \& López-Granados, 1991; Ghalwash et al., 2008 and Kenapar, 2009).

Among the cultural control methods is the use of nitrogenous fertilizers. Inhibitory effects of nitrogen on the growth of broomrapes, based on field, greenhouse, and laboratories studies, have been common in the many literatures. Broomrape tends to be associated with less fertile soil conditions. Nitrogen fertilizers reduced its seed germination, growth and development (AbuIrmaileh, 1981, 1994 and Westwood \& Foy, 1999). The numbers and dry weights of shoot of branched broomrape decreased when treated with $\mathrm{N}$ fertilizer (Mariam \& Suwanketnikom, 2004). Ammonium sulfate were shown to decrease the percent seed germination and radicle elongation of crenate broomrape when applied during pre-conditioning and germination, although a greater effect was obtained when applications included the germination period (Pieterse, 1991 and Westwood \& Foy, 1999).

Intercropping is regarded as an ecological method to manage pests, diseases and weeds via natural competitive principles that allow for more efficient resource utilisation (Liebman \& Dyck, 1993). Fenugreek (Trigonella foenumgraecum L.) roots have been suggested to inhibit the Orobanche crenata germination, resulting in reduced infection of legumes when intercropped with the plant (Bakheit et al., 2002; Evidente et al., 2007; Fernandez-Aparicioa et al., 2008 and Fernandez-Aparicioa et al., 2011). The number of Orobanche crenata plants decreased when faba bean (Vicia faba L.) are intercropped with oat (Avena sativa L.) (Mallory-Smith et al.,2004; Fenandez-Aparicioa et al., 2007 and Fernandez-Aparicioa et al., 2011 ).

The objectives of this study were to determine the integrated broomrape (Orobanche crenata) control in faba bean (Vicia faba L.) with the nitrogen fertilizer, intercropped faba bean with oat or fenugreek and herbicides

\section{Materials and Methods}

Two field experiments were carried out at the farm of Sakha Agricultural Research Station, Kafrelshiekh, Egypt, during 2010-2011 and 2011-2012 faba bean growing seasons (Latitude $30^{\circ} 48^{`} \mathrm{~N}$, Longitude $31^{\circ} 35^{`} \mathrm{E}$ ). The trials studied integrated broomrape (Orobanche crenata Forsk.) control in faba bean (Vicia faba L.) cv. Giza 843 with nitrogen fertilizer, intercropped faba bean with oat (Avena sativa L.) or fenugreek (Trigonella foenum-graecum L.) and herbicides. The field was known to be naturally heavily and uniformly infested with $O$. crenata seeds. Representative soil samples were taken from each site at the depth of $0-30 \mathrm{~cm}$ from the soil surface. The experimental soil was clay in texture with $\mathrm{pH} 8.0-8.1$, organic matter $1.44-1.51 \%$ and available nitrogen 
17.2 - $18.2 \mathrm{ppm}$ in the two seasons. The procedure of soil analysis followed the methods of Black et al. (1965).

The experimental design was split plot with four replications. The main plots were assigned to herbicides, while the sub-plots were assigned to nitrogen and intercropping treatments. Herbicide treatments were: 1- Untreated, 2Glyphosate (48\% WSC) at $36 \mathrm{~g}$ a.i./fed., (fed $=$ feddan $=0.42$ hectare), (once)., 3- Glyphosate (48\% WSC) at $36 \mathrm{~g}$ a.i./fed. (twice), 4- Imazapic (10\% EC) at $20 \mathrm{~g}$ a.i./fed. (once), 5- Imazapic (10\% EC) at $20 \mathrm{~g}$ a.i./fed. (twice).The first herbicide spray applied at the beginning of faba bean flowering and the second spray was after three weeks from the first one. Herbicidal nomenclatures are listed in Table 1. Sub-plots were assigned to faba bean (Vicia faba L.) (sole crop), intercropping faba+ oats (Avena sativa L.), intercropping faba+ fenugreek (Trigonella foenum-graecum L.) and nitrogen fertilizer. Nitrogen rate was $30 \mathrm{~kg} \mathrm{~N} /$ fed in the form of $\mathrm{NH}_{4} \mathrm{NO}_{3}(33 \% \mathrm{~N})$ adding after 50 days from sowing.

TABLE 1. Trade common and chemical names of the tested herbicides

\begin{tabular}{|c|c|c|}
\hline Trade name & Common name & Chemical name \\
\hline Roundup & Glyphosate & Isopropylamine salt of N-(phosphonomethyl)glycine \\
\hline Oroban & Imazapic & $\begin{array}{c}\text { 2-[4,5-dihydro-4-methyl-4-(1-methylethyl)-5-oxo- } 1 \mathrm{H} \text { - } \\
\text { imidazol-2-yl]-5-methyl-3-pyridinecarboxylic acid }\end{array}$ \\
\hline
\end{tabular}

Sowing took place at $12^{\text {th }}$ and $13^{\text {th }}$ November in first and second seasons, respectively. Each plot consisted of five ridges each $3.5 \mathrm{~m}$ long and $60 \mathrm{~cm}$ apart. The seed of faba bean were sown in one side of the ridge in 2-seeds hill distanced $20 \mathrm{~cm}$ at sole system. At intercropping system, Seeds of faba bean were sown on one side of ridge and oats (Avena sativa L.) or fenugreek (Trigonella foenum-graecum L.) with rate $12 \mathrm{~kg} / \mathrm{fed}$ were drill on the other side. All the recommended agricultural practices for faba bean production were applied at the proper time. Calcium superphosphate fertilizer was used at the rate of $15.0 \mathrm{~kg} \mathrm{P}_{2} \mathrm{O}_{5} /$ fed during land preparation. Hoeing was applied before the first and second irrigation. Number and dry weight of broomrape spikes $/ \mathrm{m}^{2}$ were taken at plant maturity.

The percentage of reduction in broomrape spikes number $/ \mathrm{m}^{2}$ and weight $/ \mathrm{m}^{2}$ was calculated using the following equation:

$$
\text { Percentage of reduction }=\frac{\mathrm{A}-\mathrm{B}}{\mathrm{A}} \times 100
$$

where: A and B refer to number or dry weight of broomrape in the untreated and treated plots, respectively. 
The photosynthetic pigments chlorophyll ( $\mathrm{mg} / \mathrm{g}) \mathrm{a}, \mathrm{b}$ and total were estimated in samples of fresh leaves of faba bean according to Moran \& Porath (1982). The samples were taken 15 days after the $2^{\text {nd }}$ application of herbicide treatments. At harvest, plant height $(\mathrm{cm})$, number of branches/plant, number of pods/plant and weight of pods/plant $(\mathrm{g}), 100$-seed weight $(\mathrm{g})$, seed yield $(\mathrm{g} / \mathrm{plant})$, seed yield (tons/fed) and biological yield (tons/ fed) of faba bean were determined. The obtained data were subjected to analysis of variance according to Gomez \& Gomez (1984). Treatment means were compared by Duncan's Multiple Range Test (Duncan, 1955). All statistical analysis was performed using analysis of variance technique by means of MSTAT-C computer software package.

\section{Results and Discussion}

\section{Broomrape}

Number and dry weight of broomrape spikes $/ \mathrm{m}^{2}$ in faba bean as affected by broomrape control herbicides (Imazapic 10\% EC and Glyphosate 48\% WSC), intercropping with fenugreek or oat and nitrogen fertilizer in 2010/11 and 2011/2012 seasons are shown in Table 2. Broomrape control treatments had a significant effect on density and growth of broomrape parasite in both seasons. The two broomrape control herbicides substantially suppressed spikes number and dry weight of broomrape parasite weed $/ \mathrm{m}^{2}$ compared with untreated. Spikes number and dry weight of broomrape parasite weed $/ \mathrm{m}^{2}$ was markedly decreased by repeating spray of Imazapic or Glyphosate herbicides.

Foliar spray of Imazapic and Glyphosate twice on faba bean recorded a less number and dry weight of broomrape spikes $/ \mathrm{m}^{2}$ than its spray one time. Therefore, application of Imazapic or Glyphosate herbicides twice resulted in the best controlling for density and growth of broomrape parasite in both seasons. No significant differences in density and growth of broomrape parasite were detected between Imazapic and Glyphosate herbicides at each of one or two sprays. Data show that spray herbicides twice reduced number of broomrape spikes than untreated treatment by $80.7: 78.2 \%$ for Imazapic and 75.0: 73.9\% for Glyphosate in the first and second season, respectively. The maximum control efficiency of broomrape parasite weeds obtained from herbicides application may be due to effective against broomrape because of its translocation from host to parasite through the phloem (Zahran et al., 1980). These results are in harmony with those obtained with Ghalwash (2003), Ghalwash et al. (2008) and Kenapar (2009) whose reported that the action of glyphosate on broomrape is attributable to its selective accumulation in the young parasite plant up to a level four times as high as that in faba bean host root at three days after spraying. 
TABLE 2. Number and dry weight of broomrape spikes / $\mathrm{m}^{2}$ on faba bean as affected by broomrape control herbicides, intercropping with fenugreek or oat and nitrogen fertilizer and their interaction in 2010/11 and 2011/2012 seasons.

\begin{tabular}{|c|c|c|c|c|}
\hline \multirow[b]{2}{*}{ Factor } & \multicolumn{2}{|c|}{ 2010/11 season } & \multicolumn{2}{|c|}{ 2011/12 season } \\
\hline & $\begin{array}{c}\text { Spikes } \\
\left(\mathbf{N o} / \mathbf{m}^{2}\right)\end{array}$ & $\begin{array}{c}\text { Spikes dry } \\
\text { weight } \\
\left(\mathrm{g} / \mathbf{m}^{2}\right)\end{array}$ & $\begin{array}{c}\text { Spikes } \\
\left(\mathrm{No} / \mathbf{m}^{2}\right)\end{array}$ & $\begin{array}{c}\text { Spikes dry } \\
\text { weight }\left(\mathrm{g} / \mathrm{m}^{2}\right)\end{array}$ \\
\hline $\begin{array}{l}\text { Herbicide: } \\
\text { Untreated } \\
\text { Imazapic, once } \quad(\mathrm{C}) \\
\text { Glyphosate, once }\left(\mathrm{I}_{1}\right) \\
\text { Imazapic, twice } \quad\left(\mathrm{G}_{1}\right) \\
\text { Glyphosate, twice }\left(\mathrm{G}_{2}\right)\end{array}$ & $\begin{array}{c}14.1 \mathrm{a} \\
7.8 \mathrm{~b} \\
8.2 \mathrm{~b} \\
3.4 \mathrm{c} \\
4.4 \mathrm{c} \\
* *\end{array}$ & $\begin{array}{c}22.1 \mathrm{a} \\
9.8 \mathrm{~b} \\
11.5 \mathrm{~b} \\
3.7 \mathrm{c} \\
4.8 \mathrm{c} \\
* *\end{array}$ & $\begin{array}{c}15.7 \mathrm{a} \\
8.2 \mathrm{~b} \\
8.4 \mathrm{~b} \\
4.1 \mathrm{c} \\
5.1 \mathrm{c} \\
*\end{array}$ & $\begin{array}{c}24.0 \mathrm{a} \\
11.0 \mathrm{~b} \\
12.2 \mathrm{~b} \\
4.8 \mathrm{c} \\
6.1 \mathrm{c} \\
* *\end{array}$ \\
\hline $\begin{array}{l}\text { Intercropping and N : } \\
\text { Sole faba bean }(\mathrm{S}) \\
\mathrm{FB}+\text { Fenugreek }(\mathrm{F}) \\
\mathrm{FB}+\mathrm{Oat} \quad(\mathrm{O}) \\
\mathrm{FB}+\mathrm{NH}_{4} \mathrm{NO}_{3} \quad(\mathrm{~N})\end{array}$ & $\begin{array}{c}9.4 \mathrm{a} \\
6.4 \mathrm{c} \\
7.7 \mathrm{~b} \\
6.7 \mathrm{c} \\
*\end{array}$ & $\begin{array}{c}15.9 \mathrm{a} \\
7.2 \mathrm{c} \\
10.1 \mathrm{~b} \\
8.3 \mathrm{c} \\
* *\end{array}$ & $\begin{array}{c}10.2 \mathrm{a} \\
7.1 \mathrm{c} \\
8.5 \mathrm{~b} \\
7.3 \mathrm{c} \\
*\end{array}$ & $\begin{array}{c}17.7 \mathrm{a} \\
8.5 \mathrm{c} \\
10.9 \mathrm{~b} \\
9.4 \mathrm{c} \\
* *\end{array}$ \\
\hline $\begin{array}{l}\text { Interaction: } \\
\mathrm{C} \times \mathrm{S} \\
\mathrm{C} \times \mathrm{F} \\
\mathrm{C} \times \mathrm{O} \\
\mathrm{C} \times \mathrm{N} \\
\mathrm{I}_{1} \times \mathrm{S} \\
\mathrm{I}_{1} \times \mathrm{F} \\
\mathrm{I}_{1} \times \mathrm{O} \\
\mathrm{I}_{1} \times \mathrm{N} \\
\mathrm{G}_{1} \times \mathrm{S} \\
\mathrm{G}_{1} \times \mathrm{F} \\
\mathrm{G}_{1} \times \mathrm{O} \\
\mathrm{G}_{1} \times \mathrm{N} \\
\mathrm{I}_{2} \times \mathrm{S} \\
\mathrm{I}_{2} \times \mathrm{F} \\
\mathrm{I}_{2} \times \mathrm{O} \\
\mathrm{I}_{2} \times \mathrm{N} \\
\mathrm{G}_{2} \times \mathrm{S} \\
\mathrm{G}_{2} \times \mathrm{F} \\
\mathrm{G}_{2} \times \mathrm{O} \\
\mathrm{G}_{2} \times \mathrm{N}\end{array}$ & $\begin{array}{c}17.6 \mathrm{a} \\
11.9 \mathrm{c} \\
14.4 \mathrm{~b} \\
12.6 \mathrm{c} \\
9.7 \mathrm{~d} \\
6.6 \mathrm{~g} \\
7.9 \mathrm{ef} \\
6.9 \mathrm{fg} \\
10.2 \mathrm{~d} \\
6.9 \mathrm{fg} \\
8.3 \mathrm{e} \\
7.3 \mathrm{efg} \\
4.2 \mathrm{ij} \\
2.9 \mathrm{k} \\
3.5 \mathrm{ijk} \\
3 \mathrm{jk} \\
5.4 \mathrm{~h} \\
3.7 \mathrm{ijk} \\
4.5 \mathrm{hi} \\
3.9 \mathrm{ijk} \\
*\end{array}$ & $\begin{array}{c}33.0 \mathrm{a} \\
14.3 \mathrm{~d} \\
23.5 \mathrm{~b} \\
17.5 \mathrm{c} \\
17.0 \mathrm{c} \\
6.8 \mathrm{fg} \\
8.3 \mathrm{ef} \\
7.2 \mathrm{fg} \\
17.6 \mathrm{c} \\
8.5 \mathrm{ef} \\
10.3 \mathrm{e} \\
9.5 \mathrm{e} \\
5.2 \mathrm{gh} \\
2.8 \mathrm{i} \\
3.6 \mathrm{hi} \\
3.2 \mathrm{hi} \\
6.8 \mathrm{fg} \\
3.8 \mathrm{hi} \\
4.6 \mathrm{hi} \\
4 \mathrm{hi} \\
*\end{array}$ & $\begin{array}{c}19.3 \mathrm{a} \\
13.6 \mathrm{c} \\
16 \mathrm{~b} \\
13.8 \mathrm{c} \\
10 \mathrm{de} \\
7.1 \mathrm{fg} \\
8.3 \mathrm{f} \\
7.3 \mathrm{fg} \\
10.3 \mathrm{~d} \\
7.2 \mathrm{fg} \\
8.5 \mathrm{ef} \\
7.4 \mathrm{fg} \\
5.2 \mathrm{hi} \\
3.3 \mathrm{j} \\
4.3 \mathrm{ij} \\
3.7 \mathrm{ij} \\
6.2 \mathrm{gh} \\
4.4 \mathrm{ij} \\
5.2 \mathrm{hi} \\
4.4 \mathrm{ij} \\
*\end{array}$ & $\begin{array}{c}36.2 \mathrm{a} \\
16.3 \mathrm{~d} \\
23.9 \mathrm{~b} \\
19.6 \mathrm{c} \\
17.7 \mathrm{~cd} \\
8.3 \mathrm{efg} \\
9.2 \mathrm{ef} \\
8.9 \mathrm{ef} \\
19 \mathrm{~cd} \\
9.1 \mathrm{ef} \\
11.2 \mathrm{e} \\
9.3 \mathrm{ef} \\
6.9 \mathrm{fgh} \\
3.6 \mathrm{i} \\
4.6 \mathrm{hi} \\
4 \mathrm{hi} \\
8.7 \mathrm{ef} \\
5.1 \mathrm{hi} \\
5.7 \mathrm{ghi} \\
5 \mathrm{hi} \\
*\end{array}$ \\
\hline
\end{tabular}

$\mathrm{FB}=$ Faba bean

$*$ and $* *$ NS indicate $\mathrm{P}<0.05, \mathrm{P}<0.01$ and not significant, respectively. Means of each factor designated by the same latter are not significantly different at $5 \%$ level using DMRT

Intercropping faba bean with some winter crops and nitrogen fertilizer significantly influenced spikes number and dry weight of broomrape parasite weed $/ \mathrm{m}^{2}$ in both seasons. Spikes number and dry weight of broomrape parasite weed $/ \mathrm{m}^{2}$ were significantly decrease on faba bean intercropped with fenugreek and oat or fertilized with ammonium nitrate $\left(\mathrm{NH}_{4} \mathrm{NO}_{3}\right)$ compared with sole faba bean without $\mathrm{N}$ fertilizer in both seasons. Intercropping faba bean with fenugreek recorded the lowest number and dry weight of broomrape spikes $/ \mathrm{m}^{2}$

Egypt. J. Agron. 34, No. 2 (2012) 
followed by application of $\mathrm{N}$ fertilizer then oat in the two seasons. Application of fenugreek or $\mathrm{N}$ fertilizer with faba bean resulted in a decrease in number of broomrape spikes $/ \mathrm{m}^{2}$ by $>61 \%$ and dry weight of spike by $>73 \%$ than sole faba bean without $\mathrm{N}$ fertilizer in both seasons. Generally, fenugreek and oat roots had inhibitory effect on broomrape. This is possibly due to release allelochemicals from fenugreek and oat roots. Previous reports on the beneficial effect of intercropping with fenugreek were inconclusive and conflicting, with some authors suggesting a beneficial effect of fenugreek when intercropped with faba bean for O. crenata (Bakheit et al., 2002) or O. foetida (Kharrat \& Halila, 2005) control in the field, and others denying it (Khalaf, 1994). Fernandez-Aparicio et al. (2008) attributed the decrease of O. crenata infection to an allelopathic interference on the parasitic life cycle at the level of germination. Inhibition of $O$. crenata seed germination by allelochemicals released by fenugreek roots is suggested as the mechanism for reduction of $O$. crenata infection. This has been confirmed in a subsequent work, and trigoxazonane identified from fenugreek root exudates might be responsible for the inhibition of $O$. crenata seed germination (Evidente et al., 2007). Fernandez-Aparicio et al. (2011), also shows that intercrops with cereals or with fenugreek can reduce $O$. crenata on legumes being allelopathy a major component for the reduction. However, $\mathrm{N}$ fertilizer decreased the density and growth of broomrape parasite, may be through its effect on reducing potassium uptake, since broomrape seeds had a high demand for potassium (Abu-Irmaileh, 1994).

Also, the reduction in broomrape parasite infestation with ammonium nitrate $\left(\mathrm{NH}_{4} \mathrm{NO}_{3}\right)$ could be attributed mainly to $\mathrm{N}$ role in the stimulation of various physiological processes including cell division and cell elongation resulting in more photosynthetic area and photosynthetic pigments content, which resulted in more photosynthetic production and consequently improved crop performance and tolerance to attack by parasite (Jain \& Foy,1992). Several researchers have reported that broomrape infestation in vivo can be suppressed by nitrogen fertilization (Abu-Irmaileh, 1981 and Jain \& Foy, 1992). The integration between herbicides and intercropping faba bean with fenugreek and oat or fertilization with $\mathrm{NH}_{4} \mathrm{NO}_{3}$ had a significant effect on number and dry weight of broomrape spikes $/ \mathrm{m}^{2}$ in both seasons. All combinations of herbicides and intercropping or $\mathrm{N}$ fertilizer resulted in a significant reduction in number and dry weight of broomrape spikes $/ \mathrm{m}^{2}$ compared with sole faba bean without either herbicides or $\mathrm{N}$ fertilizer in both seasons. Data in Table 2 and Fig. 1, 2, 3 and 4 show that application of herbicides along with intercropping fenugreek with faba bean substantially suppressed number and dry weight of broomrape spikes $/ \mathrm{m}^{2}$ than single application of each one in both seasons. 


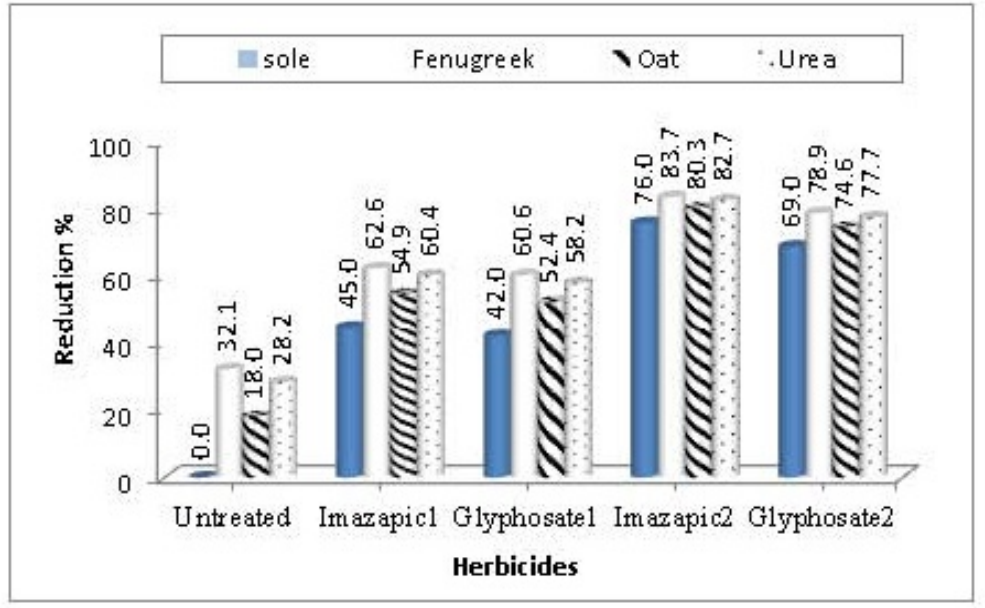

Fig. 1. Percentage of reduction in broomrape spikes number $/ \mathrm{m}^{2}$ in faba bean as affected by broomrape control herbicides, intercropping with fenugreek or oat and nitrogen fertilizer in 2010/11 season.

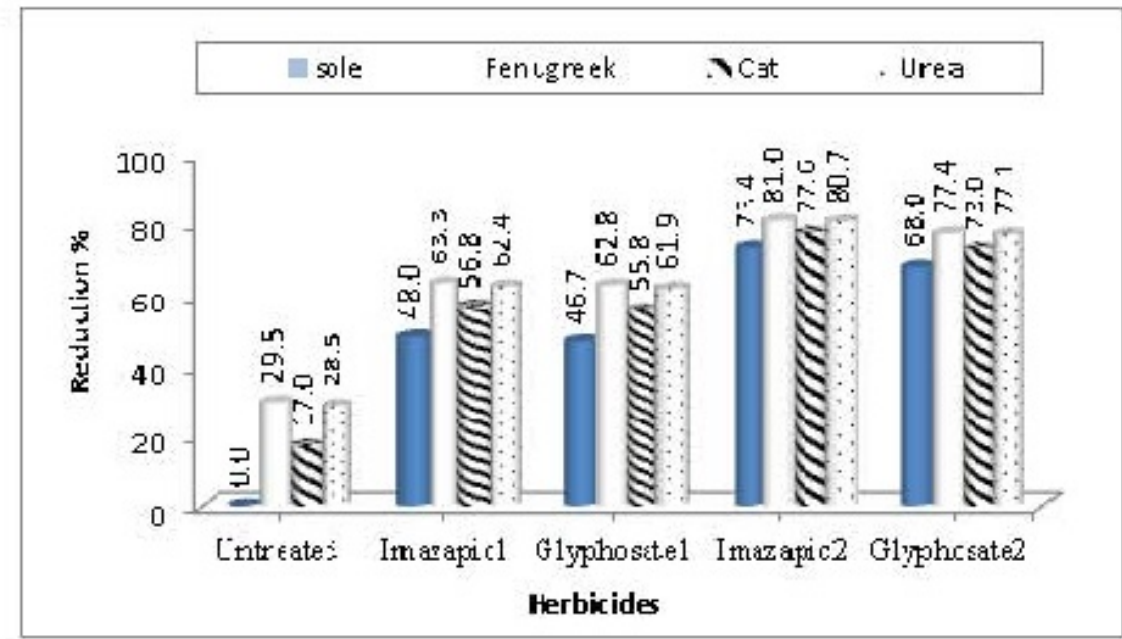

Fig. 2. Percentage of reduction in broomrape spikes number $/ \mathrm{m}^{2}$ in faba bean as affected by broomrape control herbicides, intercropping with fenugreek or oat and nitrogen fertilizer in 2011/12 season.

Egypt. J. Agron. 34, No. 2 (2012) 


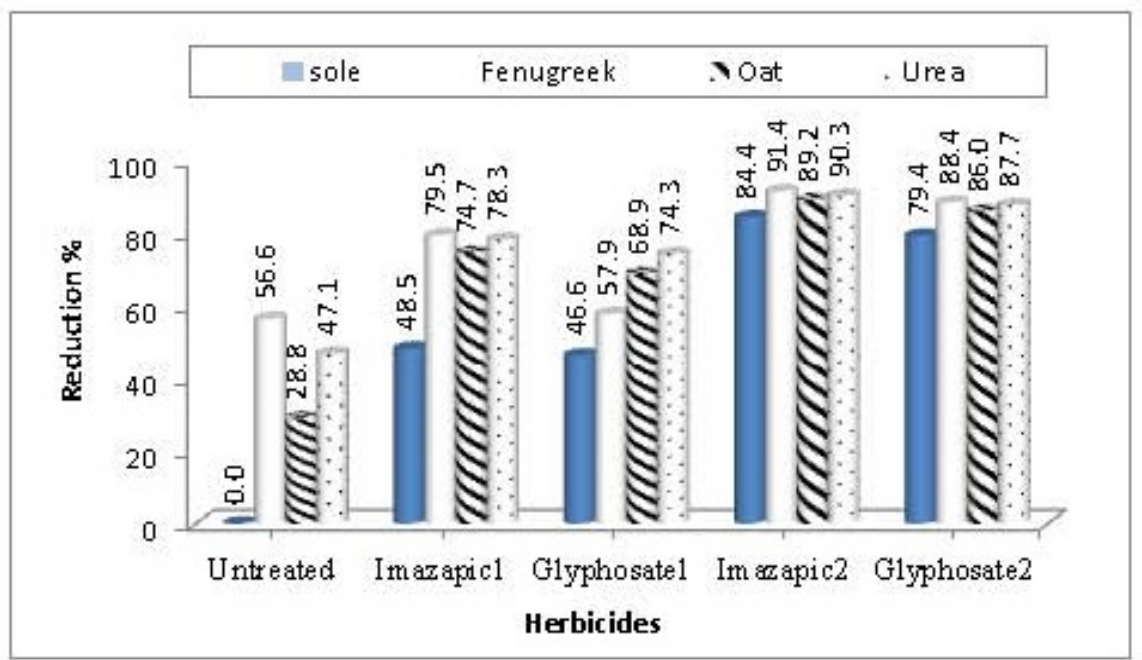

Fig. 3. Percentage of reduction in broomrape spikes dry weight $/ \mathrm{m}^{2}$ in faba bean as affected by broomrape control herbicides, intercropping with fenugreek or oat and nitrogen fertilizer in 2010/11 season.

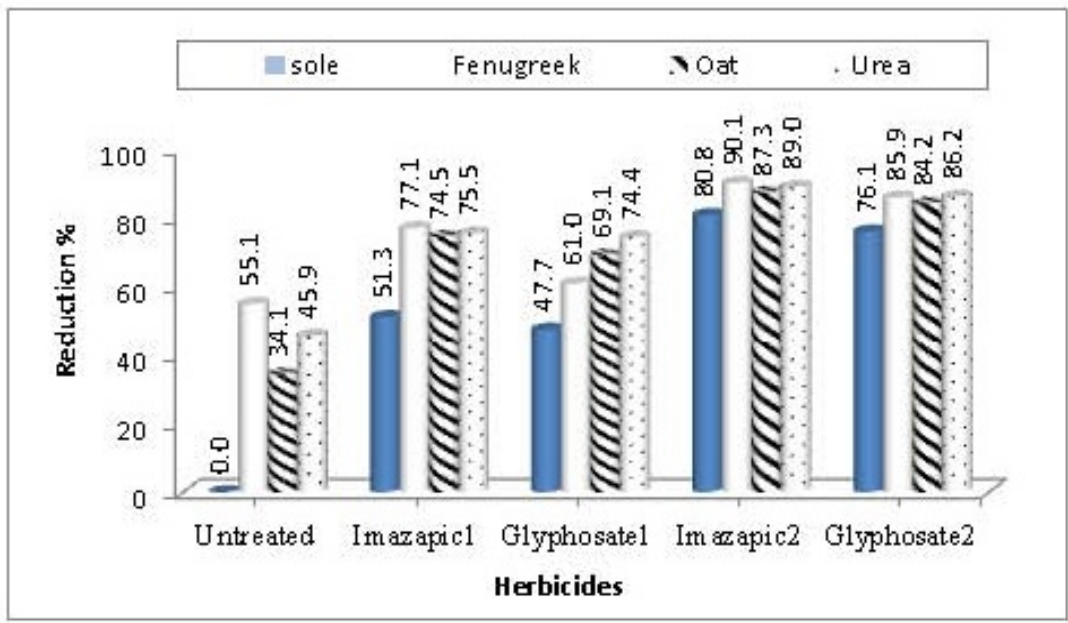

Fig. 4. Percentage of reduction in broomrape spikes dry weight $/ \mathrm{m}^{2}$ in faba bean as affected by broomrape control herbicides, intercropping with fenugreek or oat and nitrogen fertilizer in 2011/12. 
Repeating spray of Imazapic or Glyphosate herbicides markedly reduced number and dry weight of broomrape spikes $/ \mathrm{m}^{2}$ at the same intercropping or $\mathrm{NH}_{4} \mathrm{NO}_{3}$ treatments in the two seasons. Foliar spray of Imazapic twice on faba bean intercropped with fenugreek recorded a less number and dry weight of broomrape spikes $/ \mathrm{m}^{2}$. There were no significant differences in spikes number and dry weight of broomrape parasite weed $/ \mathrm{m}^{2}$ among application of fenugreek and oat or ammonium nitrate $\left(\mathrm{NH}_{4} \mathrm{NO}_{3}\right)$ fertilizer with spraying Imazapic or Glyphosate twice in both seasons. Figures 1 and 2 show that the reduction in broomrape spikes number $/ \mathrm{m}^{2}$ was ranged from 29.5: $32.1 \%$ for fenugreek, 17.0 : $18.0 \%$ for oat and 28.2:28.5\% for $\mathrm{NH}_{4} \mathrm{NO}_{3}$ without herbicides and 45.0: $48.0 \%$ for Imazapic once, $42.0: 46.7 \%$ for Glyphosate once, $73.4: 76.0 \%$ for Imazapic twice, 68.0: $69.0 \%$ for Glyphosate twice separately as well as 81.0: $83.7 \%$ for fenugreek with Imazapic twice and 80.7: 82.7\% for $\mathrm{NH}_{4} \mathrm{NO}_{3}$ with Imazapic twice in the first and second season. Also, Fig. 3 and 4 show that the reduction in broomrape spikes dry weight $/ \mathrm{m}^{2}$ was ranged from $55.1: 56.6 \%$ for fenugreek, $28.8: 34.1 \%$ for oat and 45.9: $47.1 \%$ for $\mathrm{NH}_{4} \mathrm{NO}_{3}$ without herbicides and $48.5: 51.3 \%$ for Imazapic once, 46.6: $47.7 \%$ for Glyphosate once, 80.8: $84.4 \%$ for Imazapic twice, $76.1: 79.4 \%$ for Glyphosate twice separately as well as $90.1: 91.4 \%$ for fenugreek with Imazapic twice and 89.0: $90.3 \%$ for $\mathrm{NH}_{4} \mathrm{NO}_{3}$ with Imazapic twice in the first and second season. The greatest reduction in number $(>82 \%)$ and dry weight $(>90 \%)$ of broomrape spikes $/ \mathrm{m}^{2}$ were obtained by application of fenugreek along with Imazapic herbicides twice in both seasons. However, the highest values of these traits were obtained from plots of Untreated without $\mathrm{N}$ fertilizer in the two seasons. Therefore, spraying of Imazapic or Glyphosate herbicides twice on faba bean intercropped with fenugreek and oat or fertilized by ammonium nitrate $\left(\mathrm{NH}_{4} \mathrm{NO}_{3}\right)$ resulted in the best controlling for density and growth of broomrape parasite in both seasons. The maximum control efficiency of broomrape parasite weeds obtained from the integration of the mentioned treatments through inhibition of $O$. crenata seed germination by allelochemicals released by fenugreek roots or oat (Fernandez-Aparicioa et al.,2008), and mortality due to phytotoxic effect of herbicide on broomrape parasite weeds.

\section{Faba bean}

Photosynthetic pigments content

Photosynthetic pigments content (chlorophyll a, b and total chlorophyll) in leaves of faba bean plants as affected by broomrape control herbicides (Imazapic 10\% EC and Glyphosate 48\% WSC), intercropping with fenugreek or oat and nitrogen fertilizer in 2010/11 and 2011/2012 seasons are shown in Table 3. Application of broomrape control herbicides had a significant effect on chlorophyll a, b and total chlorophyll in the two seasons. Repeating foliar spray with either Imazapic $10 \%$ EC or Glyphosate $48 \%$ WSC on faba bean plants resulted in a significant decrease in all estimated photosynthetic pigments content in leaves compared with Untreated treatment in both seasons. The lowest values of photosynthetic pigments content were recorded by spraying Imazapic $10 \%$ EC or Glyphosate $48 \%$ WSC twice. In this connection, El-Hattab et al. (1987) found that chlorophyll a, b and total chlorophyll content decreased by increasing the dose of glyphosate. They reported that glyphosate induced phytotoxicity on decreasing the chlorophyll a, b and total chlorophyll content in the leaves of faba bean. Data in Table 3 show that chlorophyll $a, b$ and total chlorophyll contents were significantly greater in leaves of faba bean fertilized by $\mathrm{N}$ fertilizer than in those of sole faba bean plants without $\mathrm{N}$ fertilizer or Egypt. J. Agron. 34, No. 2 (2012) 
intercropped with fenugreek or oat in both seasons. The beneficial effects of nitrogen in increasing photosynthetic pigments content were reported by ElHattab et al. (1987). The interaction between broomrape control herbicides and intercropping had a significant effect on chlorophyll a, b and total chlorophyll content in both seasons. At the same herbicide treatment, photosynthetic pigments content were increased in leaves of faba bean fertilized by $\mathrm{N}$ fertilizer in the form of ammonium nitrate $\left(\mathrm{NH}_{4} \mathrm{NO}_{3}\right)$ than those of sole faba bean or intercropped with oat. Repeating spray of herbicides decreased these traits at any intercropping treatment. Sole faba bean plants fertilized by $\mathrm{NH}_{4} \mathrm{NO}_{3}$ recorded the highest values of photosynthetic pigments content (chlorophyll a, b and total chlorophyll) in its leaves in both seasons.

TABLE 3. Photosynthetic pigments content (chlorophyll a, b and total chlorophyll) in leaves of faba bean plants as affected by broomrape control herbicides, intercropping and nitrogen fertilizer in 2010/11 and 2011/2012 seasons.

\begin{tabular}{|c|c|c|c|c|c|c|}
\hline \multirow{3}{*}{ Factor } & \multirow{2}{*}{\multicolumn{3}{|c|}{$\begin{array}{c}\text { 2010/11 season } \\
\text { Chlorophyll }(\mathrm{gm} / \mathrm{g})\end{array}$}} & \multirow{2}{*}{\multicolumn{3}{|c|}{$\begin{array}{c}\text { 2011/12 season } \\
\text { Chlorophyll }(\mathrm{gm} / \mathrm{g})\end{array}$}} \\
\hline & & & & & & \\
\hline & $\mathbf{a}$ & b & Total & $\mathbf{a}$ & b & Total \\
\hline \multicolumn{7}{|l|}{ Herbicide: } \\
\hline Untreated $\quad$ (C) & $4.21 \mathrm{a}$ & $1.64 \mathrm{a}$ & $7.31 \mathrm{a}$ & $4.28 \mathrm{a}$ & $2.08 \mathrm{a}$ & $7.82 \mathrm{a}$ \\
\hline Imazapic, once $\quad\left(\mathrm{I}_{1}\right)$ & $4.19 \mathrm{a}$ & $1.56 \mathrm{ab}$ & $7.17 \mathrm{a}$ & $4.35 \mathrm{a}$ & $1.94 \mathrm{ab}$ & $7.73 \mathrm{a}$ \\
\hline Glyphosate, once $\left(\mathrm{G}_{1}\right)$ & $3.77 \mathrm{~b}$ & $1.5 \mathrm{ab}$ & $6.59 \mathrm{~b}$ & $3.91 \mathrm{~b}$ & $1.75 \mathrm{bc}$ & $7.04 \mathrm{~b}$ \\
\hline Imazapic, twice $\quad\left(\mathrm{I}_{2}\right)$ & $3.61 \mathrm{~b}$ & $1.34 \mathrm{c}$ & $6.18 \mathrm{~b}$ & $3.75 \mathrm{~b}$ & $1.6 \mathrm{c}$ & $6.61 \mathrm{~b}$ \\
\hline Glyphosate, twice $\left(\mathrm{G}_{2}\right)$ & $\begin{array}{l}3.63 \mathrm{~b} \\
* *\end{array}$ & $\begin{array}{c}1.48 \mathrm{bc} \\
*\end{array}$ & $\begin{array}{c}6.41 \mathrm{~b} \\
*\end{array}$ & $\begin{array}{c}3.78 \mathrm{~b} \\
*\end{array}$ & $\begin{array}{c}1.77 \mathrm{bc} \\
*\end{array}$ & $\begin{array}{l}6.87 \mathrm{~b} \\
* *\end{array}$ \\
\hline \multicolumn{7}{|l|}{ Intercropping and N : } \\
\hline Sole faba bean (S) & $3.51 \mathrm{c}$ & $1.43 \mathrm{bc}$ & $6.18 \mathrm{c}$ & $3.71 \mathrm{c}$ & $1.7 \mathrm{~b}$ & $6.69 \mathrm{c}$ \\
\hline $\mathrm{FB}+$ Fenugreek $(\mathrm{F})$ & $4.01 \mathrm{~b}$ & $1.53 \mathrm{~b}$ & $6.92 \mathrm{~b}$ & $4.11 \mathrm{~b}$ & $1.85 \mathrm{~b}$ & $7.4 \mathrm{~b}$ \\
\hline $\mathrm{FB}+\mathrm{Oat}$ & $3.71 \mathrm{c}$ & $1.4 \mathrm{c}$ & $6.39 \mathrm{c}$ & $3.79 \mathrm{c}$ & $1.69 \mathrm{~b}$ & $6.77 \mathrm{c}$ \\
\hline $\mathrm{FB}+\mathrm{NH}_{4} \mathrm{NO}_{3}$ & $\begin{array}{c}4.29 \mathrm{a} \\
* *\end{array}$ & $\begin{array}{c}1.65 \mathrm{a} \\
*\end{array}$ & $\begin{array}{c}7.43 \mathrm{a} \\
* *\end{array}$ & $\begin{array}{l}4.44 \mathrm{a} \\
* *\end{array}$ & $\begin{array}{c}2.08 \mathrm{a} \\
*\end{array}$ & $\begin{array}{c}7.99 \mathrm{a} \\
*\end{array}$ \\
\hline \multicolumn{7}{|l|}{ Interaction: } \\
\hline $\mathrm{C} \times \mathrm{S}$ & $3.74 \mathrm{e}$ & $1.48 \mathrm{def}$ & $6.52 \mathrm{efg}$ & $3.97 \mathrm{def}$ & $1.93 \mathrm{~cd}$ & $7.26 \mathrm{def}$ \\
\hline $\mathrm{C} \times \mathrm{F}$ & $4.4 \mathrm{ab}$ & $1.63 \mathrm{bcd}$ & $7.51 \mathrm{abc}$ & $4.54 \mathrm{a}$ & $2.07 \mathrm{abc}$ & $8.05 \mathrm{ab}$ \\
\hline $\mathrm{C} \times \mathrm{O}$ & $4.2 \mathrm{c}$ & $1.72 \mathrm{abc}$ & $7.42 \mathrm{abc}$ & $4 \mathrm{de}$ & $2.11 \mathrm{ab}$ & $7.64 \mathrm{~cd}$ \\
\hline $\mathrm{C} \times \mathrm{N}$ & $4.49 \mathrm{a}$ & $1.74 \mathrm{abc}$ & $7.79 \mathrm{a}$ & $4.61 \mathrm{a}$ & $2.21 \mathrm{a}$ & $8.33 \mathrm{a}$ \\
\hline $\mathrm{I}_{1} \times \mathrm{S}$ & $3.83 \mathrm{e}$ & $1.61 \mathrm{bcd}$ & $6.82 \mathrm{de}$ & $4.1 \mathrm{~cd}$ & $1.94 \mathrm{~cd}$ & 7.42 cde \\
\hline $\mathrm{I}_{1} \times \mathrm{F}$ & $4.32 \mathrm{bc}$ & $1.69 \mathrm{abc}$ & $7.51 \mathrm{abc}$ & $4.28 \mathrm{a}-\mathrm{d}$ & $2.17 \mathrm{a}$ & $8.05 \mathrm{ab}$ \\
\hline $\mathrm{I}_{1} \times \mathrm{O}$ & $4.2 \mathrm{c}$ & $1.17 \mathrm{~h}$ & $6.63 \mathrm{def}$ & $4.49 \mathrm{abc}$ & $1.42 \mathrm{jk}$ & 7.21 ef \\
\hline $\mathrm{I}_{1} \times \mathrm{N}$ & $4.4 \mathrm{ab}$ & $1.76 \mathrm{ab}$ & $7.7 \mathrm{a}$ & $4.52 \mathrm{ab}$ & $2.23 \mathrm{a}$ & $8.25 \mathrm{a}$ \\
\hline $\mathrm{G}_{1} \times \mathrm{S}$ & $3.41 \mathrm{fg}$ & 1.44 ef & $6.07 \mathrm{gh}$ & $3.6 \mathrm{fgh}$ & $1.56 \mathrm{~g}-\mathrm{j}$ & $6.49 \mathrm{hi}$ \\
\hline $\mathrm{G}_{1} \times \mathrm{F}$ & $4.01 \mathrm{~d}$ & $1.32 \mathrm{fg}$ & $6.62 \mathrm{def}$ & $4.14 \mathrm{bcd}$ & $1.47 \mathrm{ijk}$ & $6.92 \mathrm{fg}$ \\
\hline $\mathrm{G}_{1} \times \mathrm{O}$ & $3.46 \mathrm{f}$ & $1.43 \mathrm{ef}$ & $6.12 \mathrm{fgh}$ & $3.59 \mathrm{fgh}$ & $1.74 \mathrm{f}$ & $6.63 \mathrm{gh}$ \\
\hline $\mathrm{G}_{1} \times \mathrm{N}$ & $4.2 \mathrm{c}$ & $1.82 \mathrm{a}$ & $7.56 \mathrm{ab}$ & $4.3 \mathrm{a}-\mathrm{d}$ & $2.21 \mathrm{a}$ & $8.11 \mathrm{ab}$ \\
\hline $\mathrm{I}_{2} \times \mathrm{S}$ & $3.26 \mathrm{~g}$ & $1.22 \mathrm{gh}$ & $5.59 \mathrm{~h}$ & $3.3 \mathrm{~h}$ & $1.36 \mathrm{k}$ & $5.81 \mathrm{j}$ \\
\hline $\mathrm{I}_{2} \times \mathrm{F}$ & $3.45 \mathrm{f}$ & $1.43 \mathrm{ef}$ & $6.12 \mathrm{fgh}$ & $3.66 \mathrm{e}-\mathrm{h}$ & $1.68 \mathrm{fgh}$ & $6.63 \mathrm{gh}$ \\
\hline $\mathrm{I}_{2} \times \mathrm{O}$ & $3.36 \mathrm{fg}$ & $1.33 \mathrm{fg}$ & $5.87 \mathrm{~h}$ & $3.47 \mathrm{~h}$ & $1.62 \mathrm{f}-\mathrm{i}$ & $6.26 \mathrm{hi}$ \\
\hline $\mathrm{I}_{2} \times \mathrm{N}$ & $4.37 \mathrm{ab}$ & $1.38 \mathrm{f}$ & $7.13 \mathrm{bcd}$ & $4.55 \mathrm{a}$ & 1.75 ef & $7.76 \mathrm{bc}$ \\
\hline $\mathrm{G}_{2} \times \mathrm{S}$ & $3.31 \mathrm{fg}$ & $1.39 \mathrm{f}$ & $5.89 \mathrm{~h}$ & $3.57 \mathrm{gh}$ & $1.69 \mathrm{fg}$ & $6.47 \mathrm{hi}$ \\
\hline $\mathrm{G}_{2} \times \mathrm{F}$ & $3.87 \mathrm{de}$ & $1.6 \mathrm{bcd}$ & $6.85 \mathrm{de}$ & $3.92 \mathrm{~d}-\mathrm{g}$ & $1.89 \mathrm{de}$ & $7.36 \mathrm{de}$ \\
\hline $\mathrm{G}_{2} \times \mathrm{O}$ & $3.35 \mathrm{fg}$ & $1.37 \mathrm{fg}$ & $5.91 \mathrm{~h}$ & $3.39 \mathrm{~h}$ & $1.53 \mathrm{hij}$ & $6.13 \mathrm{ij}$ \\
\hline $\mathrm{G}_{2} \times \mathrm{N}$ & $\underset{*}{4.01 \mathrm{~d}}$ & $\begin{array}{c}1.58 \mathrm{cde} \\
*\end{array}$ & $\begin{array}{c}6.99 \text { cde } \\
*\end{array}$ & $\begin{array}{c}4.23 \mathrm{a}-\mathrm{d} \\
*\end{array}$ & $\begin{array}{c}1.99 \mathrm{bcd} \\
*\end{array}$ & $\begin{array}{c}7.52 \text { cde } \\
*\end{array}$ \\
\hline
\end{tabular}

$\mathrm{FB}=$ Faba bean. ${ }^{*}$ and ${ }^{* *}$ indicate $\mathrm{P}<0.05, \mathrm{P}<0.01$ and not significant, respectively. Means of each factor designated by the same latter are not significantly different at $5 \%$ level using DMRT 
Growth, seed yield and its attributes

Data in Tables 4 and 5 show that all herbicidal treatments significantly increased plant height, number of branches and pods/plant, 100-seed weight, seed yield/plant, seed and biological yields/fed of faba bean compared with untreated treatment in both seasons. Plots sprayed twice with of Imazapic herbicide significantly exceeded those sprayed once with Imazapic or Glyphosate herbicides in seed and biological yields as well as its attributes in both seasons. Such increases in seed yield per feddan obtained from the mentioned treatments may be attributed to successful control broomrape parasite weed which reduced competition and consequently favored growth of faba bean plants, yield attributes (number of branches and pods/plant, 100-seed weight and seed yield/plant) and consequently seed yield. In this connection, Fayed et al. (2002) found a significant negative correlation between seed yield of faba bean and number of Orobanche $/ \mathrm{m}^{2}$. These results are in agreement with those obtained by Ghalwash (2003), Ghalwash et al. (2008) and Kenapar (2009).

Plant height, seed and biological yields and its attributes of faba bean were significantly affected by intercropping and $\mathrm{N}$ fertilizer in both seasons. Faba been intercropped with fenugreek or fertilized with $\mathrm{NH}_{4} \mathrm{NO}_{3}$ produced significantly taller plants and greater seed and biological yields as well as its attributes than did sole faba bean without $\mathrm{N}$ fertilizer in both seasons. Such increases in grain yield obtained from the mentioned treatments may be attributed to successful control broomrape parasite weeds which reduced competition and consequently favored growth of faba been plants, yield attributes and 100-grain weight and consequently seed yield. The increase in seed yield might be due to increased availability of nitrogen causing accelerated photosynthetic rate and thus leading to the production of more carbohydrates, consequently it improved faba bean plant growth and development of yield attributes which in turn resulted in increasing seed yield. Also, this may be due to rapid growth of faba bean plants by adding nitrogen fertilizer, which resulted in improving the competitive ability of faba bean to suppress density and growth broomrape parasite weed.

The interaction of herbicides and intercropping had a significant effect on number and weight of pods/plant and seed yield per plant as well as per feddan in both seasons (Table 6). The combination of Imazapic herbicide twice and fenugreek recorded the highest values of these traits, while sole faba bean plants without $\mathrm{N}$ fertilizer and Untreated produced the lowest ones in both seasons. Faba bean intercropped with fenugreek or fertilized with $\mathrm{NH}_{4} \mathrm{NO}_{3}$ and sprayed twice by Imazapic 10\% EC herbicide produced significantly greater seed yield than each of them application alone in both seasons. 
INTEGRATED BROOMRAPE (OROBANCHE CRENATA FORSK)...

TABLE 4. Plant height, number of branches, number of pods and weight of pods of faba bean as affected by broomrape control herbicides, intercropping with fenugreek or oat and nitrogen fertilizer in 2010/11 and 2011/12 seasons.

\begin{tabular}{|c|c|c|c|c|}
\hline Factor & $\begin{array}{c}\text { Plant } \\
\text { height } \\
(\mathbf{c m})\end{array}$ & $\begin{array}{l}\text { Branches } \\
\text { (no/plant) }\end{array}$ & $\begin{array}{c}\text { Pods } \\
\text { (no/plant) }\end{array}$ & $\begin{array}{c}\text { Pods } \\
\text { weight } \\
\text { (g/plant) }\end{array}$ \\
\hline \multicolumn{5}{|c|}{ 2010/11season } \\
\hline \multicolumn{5}{|l|}{ Herbicide: } \\
\hline Untreated $\quad$ (C) & $90 \mathrm{c}$ & $2.3 \mathrm{c}$ & $3.8 \mathrm{c}$ & $11.1 \mathrm{c}$ \\
\hline Imazapic, once $\quad\left(\mathrm{I}_{1}\right)$ & $95.6 \mathrm{~b}$ & $2.9 \mathrm{bc}$ & $5.4 \mathrm{bc}$ & $15.7 \mathrm{bc}$ \\
\hline Glyphosate, once $\left(\mathrm{G}_{1}\right)$ & $95.1 \mathrm{~b}$ & $2.8 \mathrm{c}$ & $5.3 \mathrm{bc}$ & $15.1 \mathrm{c}$ \\
\hline Imazapic, twice $\quad\left(\mathrm{I}_{2}\right)$ & $105.9 \mathrm{a}$ & $4.1 \mathrm{a}$ & $8.5 \mathrm{a}$ & $25.9 \mathrm{a}$ \\
\hline Glyphosate, twice $\left(\mathrm{G}_{2}\right)$ & $\begin{array}{c}102.3 \mathrm{a} \\
*\end{array}$ & $\begin{array}{c}3.4 \mathrm{ab} \\
* *\end{array}$ & $\begin{array}{c}6.9 \mathrm{ab} \\
*\end{array}$ & $\begin{array}{l}20.7 \mathrm{ab} \\
\quad *\end{array}$ \\
\hline \multicolumn{5}{|l|}{ Intercropping and $\mathrm{N}$ : } \\
\hline Sole faba bean (S) & $94.3 \mathrm{~b}$ & $2.8 \mathrm{~b}$ & $5.1 \mathrm{~b}$ & $15.0 \mathrm{c}$ \\
\hline FB+Fenugreek $(\mathrm{F})$ & $100.6 \mathrm{a}$ & $3.5 \mathrm{a}$ & $6.8 \mathrm{a}$ & $20.3 \mathrm{a}$ \\
\hline $\mathrm{FB}+\mathrm{Oat} \quad(\mathrm{O})$ & $97.6 \mathrm{ab}$ & $2.9 \mathrm{~b}$ & $5.8 \mathrm{ab}$ & $17.2 \mathrm{~b}$ \\
\hline $\mathrm{FB}+\mathrm{NH}_{4} \mathrm{NO}_{3} \quad(\mathrm{~N})$ & $\begin{array}{c}98.6 \mathrm{a} \\
*\end{array}$ & $\begin{array}{c}3.1 \mathrm{ab} \\
*\end{array}$ & $\begin{array}{c}6.3 \mathrm{a} \\
*\end{array}$ & $\begin{array}{c}18.4 \mathrm{ab} \\
*\end{array}$ \\
\hline \multirow[t]{2}{*}{ Interaction } & N.S. & N.S. & $*$ & $* *$ \\
\hline & \multicolumn{4}{|c|}{ 2011/12 season } \\
\hline \multicolumn{5}{|l|}{ Herbicide: } \\
\hline Untreated & $86.6 \mathrm{c}$ & $2.2 \mathrm{c}$ & $3.8 \mathrm{c}$ & $10.8 \mathrm{c}$ \\
\hline Imazapic, once $\quad\left(\mathrm{I}_{1}\right)$ & $92.4 \mathrm{~b}$ & $2.9 \mathrm{~b}$ & $5.5 \mathrm{~b}$ & $18.0 \mathrm{~b}$ \\
\hline Glyphosate, once $\left(\mathrm{G}_{1}\right)$ & $91.5 \mathrm{bc}$ & $2.8 \mathrm{~b}$ & $5.1 \mathrm{~b}$ & $16.5 \mathrm{~b}$ \\
\hline Imazapic, twice $\quad\left(\mathrm{I}_{2}\right)$ & $104.0 \mathrm{a}$ & $4.0 \mathrm{a}$ & $8.0 \mathrm{a}$ & $27.7 \mathrm{a}$ \\
\hline Glyphosate, twice $\left(\mathrm{G}_{2}\right)$ & $\begin{array}{c}100.9 \mathrm{a} \\
* *\end{array}$ & $\begin{array}{c}3.6 \mathrm{a} \\
*\end{array}$ & $\begin{array}{c}7.1 \mathrm{a} \\
*\end{array}$ & $\begin{array}{c}23.4 \mathrm{a} \\
* *\end{array}$ \\
\hline \multicolumn{5}{|l|}{ Intercropping and $\mathrm{N}$ : } \\
\hline Sole faba bean (S) & $92.2 \mathrm{~b}$ & $2.8 \mathrm{c}$ & $5.2 \mathrm{~b}$ & $16.5 \mathrm{c}$ \\
\hline $\mathrm{FB}+$ Fenugreek $(\mathrm{F})$ & $97.5 \mathrm{a}$ & $3.4 \mathrm{a}$ & $6.6 \mathrm{a}$ & $21.7 \mathrm{a}$ \\
\hline $\mathrm{FB}+\mathrm{Oat} \quad(\mathrm{O})$ & $94.9 \mathrm{ab}$ & $3 \mathrm{bc}$ & $5.8 \mathrm{ab}$ & $19 \mathrm{~b}$ \\
\hline $\mathrm{FB}+\mathrm{NH}_{4} \mathrm{NO}_{3} \quad(\mathrm{~N})$ & $\begin{array}{c}95.8 \text { a } \\
*\end{array}$ & $\begin{array}{c}3.2 \mathrm{a} \\
*\end{array}$ & $\begin{array}{c}6.1 \mathrm{a} \\
*\end{array}$ & $\begin{array}{c}19.9 \mathrm{ab} \\
*\end{array}$ \\
\hline Interaction & N.S. & N.S. & $*$ & $*$ \\
\hline
\end{tabular}

$\mathrm{FB}=$ Faba bean.

$*$, ** and $\mathrm{ns}$ indicate $\mathrm{P}<0.05, \mathrm{P}<0.01$ and not significant, respectively. Means of each factor designated by the same latter are not significantly different at $5 \%$ level using DMRT. 
TABLE 5. Seed yield, biological yield and 100-seed weight of faba bean as affected by broomrape control herbicides, intercropping with fenugreek or oat and nitrogen fertilizer in 2010/11and 2011/12 seasons.

\begin{tabular}{|c|c|c|c|c|}
\hline Factor & $\begin{array}{c}\text { 100-seed } \\
\text { weight }(\mathrm{g})\end{array}$ & $\begin{array}{c}\text { Seed yield } \\
\text { (g/plant) }\end{array}$ & $\begin{array}{l}\text { Seed yield } \\
\text { (t/fed) }\end{array}$ & $\begin{array}{c}\text { Biological } \\
\text { yield ( } t / \text { fed) }\end{array}$ \\
\hline & \multicolumn{4}{|c|}{ 2010/11 season } \\
\hline \multicolumn{5}{|l|}{ Herbicide: } \\
\hline Untreated $\quad(\mathrm{C})$ & $71.93 \mathrm{c}$ & $7.113 \mathrm{~d}$ & $0.163 \mathrm{~d}$ & $0.36 \mathrm{c}$ \\
\hline Imazapic, once $\quad\left(\mathrm{I}_{1}\right)$ & $75.5 \mathrm{~b}$ & $10.517 \mathrm{c}$ & $0.387 \mathrm{c}$ & $0.993 \mathrm{~b}$ \\
\hline Glyphosate, once $\left(\mathrm{G}_{1}\right)$ & $74.44 \mathrm{~b}$ & $10.045 \mathrm{c}$ & $0.335 \mathrm{c}$ & $0.913 \mathrm{~b}$ \\
\hline Imazapic, twice $\quad\left(\mathrm{I}_{2}\right)$ & $83.84 \mathrm{a}$ & $18.555 \mathrm{a}$ & $1.005 \mathrm{a}$ & $2.273 \mathrm{a}$ \\
\hline Glyphosate, twice $\left(\mathrm{G}_{2}\right)$ & $\begin{array}{c}80.31 \mathrm{a} \\
*\end{array}$ & $\begin{array}{c}14.367 \mathrm{~b} \\
* *\end{array}$ & $\begin{array}{c}0.682 b \\
*\end{array}$ & $\begin{array}{c}1.673 \mathrm{a} \\
*\end{array}$ \\
\hline \multicolumn{5}{|l|}{ Intercropping and $\mathrm{N}$ : } \\
\hline Sole faba bean $(\mathrm{S})$ & $75.51 \mathrm{c}$ & $10.023 \mathrm{c}$ & $0.364 \mathrm{c}$ & $0.974 \mathrm{c}$ \\
\hline FB+Fenugreek $(F)$ & $79.36 \mathrm{a}$ & $13.988 \mathrm{a}$ & $0.633 \mathrm{a}$ & $1.464 \mathrm{a}$ \\
\hline $\mathrm{FB}+\mathrm{Oat}$ & $76.29 \mathrm{bc}$ & $11.784 \mathrm{~b}$ & $0.497 \mathrm{~b}$ & $1.198 \mathrm{bc}$ \\
\hline \multirow[t]{2}{*}{$\mathrm{FB}+\mathrm{NH}_{4} \mathrm{NO}_{3} \quad(\mathrm{~N})$} & $77.64 \mathrm{ab}$ & $12.682 \mathrm{ab}$ & $0.563 \mathrm{ab}$ & $1.335 \mathrm{ab}$ \\
\hline & $*$ & $*$ & * & $*$ \\
\hline Interaction & N.S. & $*$ & $* *$ & N.S. \\
\hline \multicolumn{5}{|c|}{ 2011/12 season } \\
\hline \multicolumn{5}{|l|}{ Herbicide: } \\
\hline Untreated $\quad$ (C) & $72.38 \mathrm{c}$ & $7.351 \mathrm{c}$ & $0.224 \mathrm{~d}$ & $0.413 \mathrm{c}$ \\
\hline Imazapic, once $\quad\left(\mathrm{I}_{1}\right)$ & $79.28 \mathrm{~b}$ & $11.607 \mathrm{~b}$ & $0.502 \mathrm{c}$ & $1.326 \mathrm{~b}$ \\
\hline Glyphosate, once $\left(\mathrm{G}_{1}\right)$ & $78.78 \mathrm{~b}$ & $10.048 \mathrm{~b}$ & $0.430 \mathrm{c}$ & $1.166 \mathrm{~b}$ \\
\hline Imazapic, twice $\quad\left(\mathrm{I}_{2}\right)$ & $85.34 \mathrm{a}$ & $18.589 \mathrm{a}$ & $1.124 \mathrm{a}$ & $2.701 \mathrm{a}$ \\
\hline Glyphosate, twice $\left(\mathrm{G}_{2}\right)$ & $83.87 \mathrm{a}$ & $16.356 \mathrm{a}$ & $0.942 b$ & $2.23 \mathrm{a}$ \\
\hline & $* *$ & $*$ & * & $* *$ \\
\hline \multicolumn{5}{|l|}{ Intercropping and N : } \\
\hline Sole faba bean $(\mathrm{S})$ & $76.91 \mathrm{c}$ & $10.87 \mathrm{c}$ & $0.465 b$ & $1.305 \mathrm{c}$ \\
\hline FB+Fenugreek $(\mathrm{F})$ & $82.4 \mathrm{a}$ & $14.721 \mathrm{a}$ & $0.823 a$ & $1.806 \mathrm{a}$ \\
\hline $\mathrm{FB}+\mathrm{Oat}$ & $79.53 \mathrm{~b}$ & $12.046 \mathrm{bc}$ & $0.575 \mathrm{~b}$ & $1.528 \mathrm{bc}$ \\
\hline $\mathrm{FB}+\mathrm{NH}_{4} \mathrm{NO}_{3} \quad(\mathrm{~N})$ & $80.87 \mathrm{ab}$ & $13.525 \mathrm{ab}$ & $0.715 \mathrm{a}$ & $1.63 \mathrm{ab}$ \\
\hline & $*$ & $*$ & $*$ & $*$ \\
\hline Interaction & N.S. & $*$ & * & N.S. \\
\hline
\end{tabular}

$\mathrm{FB}=$ Faba bean. fed $=$ feddan $=0.42$ hectare.

${ }^{*}{ }^{* * *}$ and N.S. indicate $\mathrm{P}<0.05, \mathrm{P}<0.01$ and not significant, respectively. Means of each factor designated by the same latter are not significantly different at $5 \%$ level using DMRT. 
INTEGRATED BROOMRAPE (OROBANCHE CRENATA FORSK)...

TABLE 6. Seed yield and some yield attributes of faba bean as affected by the interaction between broomrape control herbicides and intercropping or nitrogen fertilizer in 2010/11 and 2011/12 seasons.

\begin{tabular}{|c|c|c|c|c|c|}
\hline \multirow[b]{2}{*}{ Intercropping and $\mathbf{N}$} & \multicolumn{5}{|c|}{ Herbicides } \\
\hline & Untreated & $\begin{array}{c}\text { Imazapic, } \\
\text { once }\end{array}$ & $\begin{array}{c}\text { Glyphosate, } \\
\text { once }\end{array}$ & $\begin{array}{c}\begin{array}{c}\text { Imazapic, } \\
\text { twice }\end{array} \\
\end{array}$ & $\begin{array}{c}\text { Glyphosate, } \\
\text { twice }\end{array}$ \\
\hline \multicolumn{6}{|c|}{$2010 / 11$ season } \\
\hline & \multicolumn{5}{|c|}{ Pods (No/plant) } \\
\hline Sole faba bean $(S)$ & $3.0 \mathrm{i}$ & 4.7 fghi & 4.7 fghi & $6.8 \mathrm{de}$ & $6.3 \mathrm{def}$ \\
\hline $\mathrm{FB}+$ Fenugreek $(\mathrm{F})$ & 4.5 fghi & 6.1 defg & $6.1 \mathrm{defg}$ & $9.9 \mathrm{a}$ & $7.3 \mathrm{bcd}$ \\
\hline $\mathrm{FB}+\mathrm{Oat}$ & $3.7 \mathrm{hi}$ & $5.0 \mathrm{efgh}$ & $4.8 \mathrm{fgh}$ & $8.7 \mathrm{abc}$ & $6.8 \mathrm{de}$ \\
\hline \multirow[t]{2}{*}{$\mathrm{FB}+\mathrm{NH}_{4} \mathrm{NO}_{3}(\mathrm{~N})$} & $4.3 \mathrm{ghi}$ & 5.7 defg & $5.7 \mathrm{defg}$ & $8.9 \mathrm{ab}$ & $7.2 \mathrm{~cd}$ \\
\hline & \multicolumn{5}{|c|}{ Pods weight (g/plant) } \\
\hline Sole faba bean (S) & $7.8 \mathrm{k}$ & $14.2 \mathrm{~g}-\mathrm{j}$ & $14.2 \mathrm{~g}-\mathrm{j}$ & 20. cde & $18.6 \mathrm{c}-\mathrm{g}$ \\
\hline $\mathrm{FB}+$ Fenugreek $(\mathrm{F})$ & 13.6 hij & $17.8 \mathrm{~d}-\mathrm{h}$ & $16.3 \mathrm{e}-\mathrm{i}$ & $30.7 \mathrm{a}$ & 23. $0 \mathrm{bc}$ \\
\hline $\mathrm{FB}+\mathrm{Oat}$ & $10.5 \mathrm{jk}$ & $15.1 \mathrm{f}-\mathrm{j}$ & $14.5 \mathrm{~g}-\mathrm{j}$ & 26. b & $19.7 \mathrm{c}-\mathrm{f}$ \\
\hline \multirow[t]{2}{*}{$\mathrm{FB}+\mathrm{NH}_{4} \mathrm{NO}_{3}(\mathrm{~N})$} & $12.5 \mathrm{ij}$ & $15.8 \mathrm{e}-\mathrm{i}$ & $15.6 \mathrm{e}-\mathrm{i}$ & $26.8 \mathrm{ab}$ & $21.5 \mathrm{~cd}$ \\
\hline & \multicolumn{5}{|c|}{ Seed yield (g/plant) } \\
\hline Sole faba bean $(\mathrm{S})$ & $4.96 \mathrm{~h}$ & $9.32 \mathrm{e}-\mathrm{h}$ & $9.218 \mathrm{e}-\mathrm{h}$ & 13.89 cde & $12.73 \mathrm{c}-\mathrm{f}$ \\
\hline $\mathrm{FB}+\mathrm{Fenugreek}(\mathrm{F})$ & $8.77 \mathrm{e}-\mathrm{h}$ & $12.13 \mathrm{c}-\mathrm{f}$ & $10.99 \mathrm{~d}-\mathrm{g}$ & $21.89 \mathrm{a}$ & $16.16 \mathrm{bc}$ \\
\hline $\mathrm{FB}+\mathrm{Oat} \quad(\mathrm{O})$ & $6.70 \mathrm{gh}$ & $10.03 \mathrm{~d}-\mathrm{g}$ & $9.55 \mathrm{e}-\mathrm{h}$ & $19.04 \mathrm{ab}$ & $13.60 \mathrm{cde}$ \\
\hline \multirow[t]{2}{*}{$\mathrm{FB}+\mathrm{NH}_{4} \mathrm{NO}_{3}(\mathrm{~N})$} & $8.02 \mathrm{fgh}$ & $10.59 \mathrm{~d}-\mathrm{g}$ & $10.42 \mathrm{~d}-\mathrm{g}$ & $19.40 \mathrm{ab}$ & $14.98 \mathrm{bcd}$ \\
\hline & \multicolumn{5}{|c|}{ Seed yield $(\mathrm{t} / \mathrm{fed})$} \\
\hline Sole faba bean $(\mathrm{S})$ & $0.098 \mathrm{k}$ & $0.277 \mathrm{~g}-\mathrm{k}$ & $0.242 \mathrm{~h}-\mathrm{k}$ & $0.668 \mathrm{bcd}$ & $0.535 \mathrm{c}-\mathrm{f}$ \\
\hline $\mathrm{FB}+$ Fenugreek $(\mathrm{F})$ & $0.223 \mathrm{~h}-\mathrm{k}$ & $0.499 \mathrm{~d}-\mathrm{g}$ & $0.443 \mathrm{e}-\mathrm{h}$ & $1.173 \mathrm{a}$ & $0.830 \mathrm{~b}$ \\
\hline $\mathrm{FB}+\mathrm{Oat}$ & $0.864 \mathrm{jk}$ & $0.351 \mathrm{f}-\mathrm{j}$ & $0.290 \mathrm{~g}-\mathrm{k}$ & $1.081 \mathrm{a}$ & $0.630 \mathrm{~b}-\mathrm{e}$ \\
\hline \multirow[t]{2}{*}{$\mathrm{FB}+\mathrm{NH}_{4} \mathrm{NO}_{3}(\mathrm{~N})$} & $0.135 \mathrm{ijk}$ & $0.420 \mathrm{e}-\mathrm{i}$ & $0.365 \mathrm{f}-\mathrm{j}$ & $1.100 \mathrm{a}$ & $0.734 \mathrm{bc}$ \\
\hline & \multicolumn{5}{|c|}{ 2011/12 season } \\
\hline & \multicolumn{5}{|c|}{ Pods (No/plant) } \\
\hline Sole faba bean (S) & $2.8 \mathrm{i}$ & $4.8 \mathrm{e}-\mathrm{i}$ & $4.5 \mathrm{f}-\mathrm{i}$ & 7.0 a-e & 6.7 a-f \\
\hline $\mathrm{FB}+$ Fenugreek $(\mathrm{F})$ & 4.3 ghi & $6.6 \mathrm{ab}-\mathrm{g}$ & $5.6 \mathrm{~b}-\mathrm{h}$ & 8.9 a & $7.3 \mathrm{abc}$ \\
\hline $\mathrm{FB}+\mathrm{Oat}$ & $3.8 \mathrm{hi}$ & $5.4 \mathrm{c}-\mathrm{h}$ & $4.9 \mathrm{~d}-\mathrm{i}$ & $7.8 \mathrm{ab}$ & 7.0 a-e \\
\hline \multirow[t]{2}{*}{$\mathrm{FB}+\mathrm{NH}_{4} \mathrm{NO}_{3}(\mathrm{~N})$} & $4.1 \mathrm{hi}$ & $5.4 \mathrm{c}-\mathrm{h}$ & $5.4 \mathrm{c}-\mathrm{h}$ & $8.3 \mathrm{a}$ & $7.2 \mathrm{a}-\mathrm{d}$ \\
\hline & \multicolumn{5}{|c|}{ Pods weight (g/plant) } \\
\hline Sole faba bean (S) & $7.4 \mathrm{j}$ & 15.4 ghi & 14.4 ghi & $23.0 \mathrm{cde}$ & $22.0 \mathrm{cdef}$ \\
\hline $\mathrm{FB}+$ Fenugreek $(\mathrm{F})$ & 13.4 ghi & $21.7 \mathrm{c}-\mathrm{f}$ & $18.3 \mathrm{~d}-\mathrm{g}$ & $30.1 \mathrm{a}$ & $25.2 \mathrm{abc}$ \\
\hline $\mathrm{FB}+\mathrm{Oat}$ & $10.4 \mathrm{ij}$ & $17.2 \mathrm{fgh}$ & $15.8 \mathrm{ghi}$ & $28.7 \mathrm{ab}$ & 22.9 cde \\
\hline \multirow[t]{2}{*}{$\mathrm{FB}+\mathrm{NH}_{4} \mathrm{NO}_{3}(\mathrm{~N})$} & $11.8 \mathrm{hij}$ & $17.5 \mathrm{e}-\mathrm{h}$ & $17.4 \mathrm{e}-\mathrm{h}$ & $28.9 \mathrm{ab}$ & $23.7 \mathrm{bcd}$ \\
\hline & \multicolumn{5}{|c|}{ Seed yield (g/plant) } \\
\hline Sole faba bean $(\mathrm{S})$ & $5.074 \mathrm{~h}$ & 9.974 efg & $9.273 \mathrm{fgh}$ & $15.25 \mathrm{bc}$ & $14.78 \mathrm{bcd}$ \\
\hline $\mathrm{FB}+$ Fenugreek $(\mathrm{F})$ & $9.696 \mathrm{fg}$ & $14.41 \mathrm{~b}-\mathrm{e}$ & $10.60 \mathrm{def}$ & $20.35 \mathrm{a}$ & $18.55 \mathrm{ab}$ \\
\hline $\mathrm{FB}+\mathrm{Oat}$ & $5.766 \mathrm{gh}$ & 10.19 efg & $10.11 \mathrm{efg}$ & $18.96 \mathrm{ab}$ & $15.20 \mathrm{bc}$ \\
\hline $\mathrm{FB}+\mathrm{NH}_{4} \mathrm{NO}_{3}(\mathrm{~N})$ & $8.870 \mathrm{fgh}$ & $11.86 \mathrm{cdef}$ & $10.21 \mathrm{efg}$ & $19.80 \mathrm{a}$ & $16.89 \mathrm{ab}$ \\
\hline & \multicolumn{5}{|c|}{ Seed yield $(\mathrm{t} / \mathrm{fed})$} \\
\hline Sole faba bean (S) & $0.119 \mathrm{k}$ & 0.349hij & $0.287 \mathrm{~h}-\mathrm{k}$ & $0.849 \mathrm{~d}$ & $0.722 \mathrm{de}$ \\
\hline $\mathrm{FB}+$ Fenugreek $(\mathrm{F})$ & 0.336hij & $0.690 \mathrm{de}$ & $0.622 \mathrm{ef}$ & $1.307 \mathrm{a}$ & $1.160 \mathrm{abc}$ \\
\hline $\mathrm{FB}+\mathrm{Oat} \quad(\mathrm{O})$ & $0.184 \mathrm{jk}$ & $0.417 \mathrm{ghi}$ & $0.360 \mathrm{hij}$ & $1.094 \mathrm{bc}$ & $0.817 \mathrm{de}$ \\
\hline $\mathrm{FB}+\mathrm{NH}_{4} \mathrm{NO}_{3}(\mathrm{~N})$ & $0.257 \mathrm{ijk}$ & $0.551 \mathrm{efg}$ & $0.449 \mathrm{fgh}$ & $1.248 \mathrm{ab}$ & $1.068 \mathrm{c}$ \\
\hline
\end{tabular}

$\mathrm{FB}=$ Faba bean. $\quad$ fed $=$ feddan $=0.42$ hectare

Means of each trait designated by the same latter are not significantly different at $5 \%$ level using DMRT. 
It can be concluded that foliar spraying with Imazapic $10 \%$ EC or Glyphosate $48 \%$ WSC twice on faba bean intercropped or fertilized with ammonium nitrate $\left(\mathrm{NH}_{4} \mathrm{NO}_{3}\right)$ could be recommended for optimum broomrape parasitic weed control and highest seed yield at Kafrelshiek Governorate.

\section{References}

Abu-Irmaileh, B.E. (1981) Response of hemp broomrape (Orobanche ramosa) infestation to some nitrogenous compounds. Weed Sci. 29, 8-10.

Abu-Irmaileh, B.E. (1994) Nitrogen reduces branched broomrape (Orobanche ramosa) seed germination. Weed Sci. 42, 57-60

Al-Rahban, B., Al-Hussein, N. and Abied, A.F. (2009) Chemical control of two Orobanche species (O. crenata and $O$. aegeptiaca) which attack lentil crop in Syria. Arab J. Plant Protection, 27, 152-158.

Black, C.A., Evans, D.D., Ensminger, L.E. and Clark, F.E. (1965) “ Methods of Soil Analysis. Part 2- Chemical and Microbiological Properties". American Soc. of Agronomy, Inc., Publisher, Madison, Wisconsin, USA.

Bakheit, B.R., Allam, A.Y. and Galal, A.H. (2002) Intercropping faba bean with some legume crops for control of Orobanche crenata. Acta Agronomica Hungarica, 50, 1-6.

Duncan, D.B. (1955) Multiple Range and Multiple F. tests. Biometrcs, 11, 1-42

El-Hattab, A.H., Hassan, E.A., Shaban, Sh. A. and Abo-El Suoud, M.R. (1987) Effect of some growth factors and glyphosate herbicide on pigments and protein in faba beans (Vicia faba L.). J. Agronomy and Crop Science, 158, 250-258

Elzein, A. and Kroschel, J., (2003) Progress on management of parasitic weeds. In: "Weed Management for Developing Countries". Labrada, R. (Ed.), Plant Production and Protection Paper, FAO, pp. 109-143.

Evidente, A., Fernandez-Aparicio, M., Andolfi, A., Rubiales, D. and Motta, A. (2007) Trigoxazonane, a monosubstituted trioxazonane by Trigonella foenumgraecum root exudate,inhibiting agent of Orobanche crenata seed germination. Phytochemistry, 68, 2487-2492.

Fayed, M.T.B., Hamdi,A., Mahamoud, M. and Shaaaban (2002) Performance of Orobanche control treatments in faba bean. Egypt. J. Agric. Res. 80(2), 753-769.

Fenandez-Aparicioa, M., Sillerob, J.C., and Rubialesa, D. (2007) Intercropping with cereals reduces infection by Orobanche crenata in legumes. Crop Protection, 26, 1166-1172

Fenandez-Aparicioa, M., Emeran, A.A. and Rubialesa, D. (2008) Control of Orobanche crenata in legumes intercropped with fenugreek (Trigonella foenumgraecum). Crop Protection, 27, 653-659. 
Fenandez-Aparicioa, M., Emeran, A.A. and Rubialesa, D. (2011) Inter-cropping faba bean with berseem, fenugreek or oat can contribute to broomrape management, Grain Legumes, 56, 31.

García-Torres, L. and López-Granados, F. (1991) Control of broomrape (Orobanche crenata Forsk.) in broad bean (Vicia faba L.) with imidazolinones and other herbicides. Weed Res. 31, 227-235

Ghalwash,A.M. (2003) Studies on broomrape weed in Egypt. Ph.D. Thesis, Fac., Agric., Minufiya Univ., Egypt.

Ghalwash,A.M., Soliman ,A.E. and Khaffagy, A.E. (2008) Performance of some faba bean (Vicia faba L.) cultivars under numerous broomrape (Orobanche crenata, Forsk) control treatments. J. Agric. Sci. Mansoura Univ. 33(4), 2439-2448.

Gomez, K.A. and Gomez, A.A. (1984) "Statistical Procedures for Agricultural Research". $2^{\text {nd }}$ ed. Johnn Wiley Sons, New York, USA.

Jain, R. and Foy., C.L. (1992) Nutrient effects on parasitism and germination of Egyptiana broomrape (Orobanche aegyptiaca). Weed Technol. 6, 269- 275

Kenapar, M.E.Z. (2009) Integrated broomrape control in faba bean fields. Ph.D. Thesis, Fac. Agric., Kafrelshiekh Univ., Egypt.

Khalaf, K.A. (1994) Intercropping fenugreek with faba bean or Egyptian clover: prospects for Orobanche crenata control. In: "Biology and Management of Orobanche" Pieters, A.H.,Verkleij, J.A.C., ter Borg, S.J. (Ed.), Proceedings of the third International Workshop on Orobanche and related Striga research. Royal Tropical Institute, Amsterdam, The Netherlands, pp. 502-504.

Kharrat, M. and Halila, M.H. (2005) Evaluation d'autres moyens de lutte contre l'Orobanche foetida Poir. sur Vicia faba L. In: “Advances in Parasitic Weed Control at On-farm Level” Kroschel, J., Abderabihi, M., Betz, H. (Ed.), Vol. II. Joint Action to Control Orobanche in the WANA Region. Margraf Verlag, Weikersheim, Germany, pp. 259-264

Liebman, M. and Dyck, E. (1993) Crop rotation and intercropping strategies for weed management. Ecol. Appl. 3 (1), 92-122.

Mallory-Smith, C.A., Colquhoun, J.B. and Ross, K.C. (2004) Small broomrape (Orobanche minor) germination and early development in response to plant species. Weed Sci. 52 (2), 260-266.

Mariam, E.G. and Suwanketnikom, R. (2004) Effect of nitrogen fertilizers on branched broomrape (Orobanche ramosa L.) in Tomato (Lycopersicon esculentum Mill.). Kasetsart J. (Nat. Sci.), 38, 311 - 319.

Moran, R. and Porath, D. (1982) Chlorophyll determination in intact tissues using N, N-Dimethyl formamid. Plant Physiol. 69, 1370-1381.

Nandula, V.K. (1998) Selective control of Egyptian broomrape (Orobanche aegyptiaca PERS.) by glyphosate and its amino acid status in relation to selected hosts. Ph.D. 
Thesis in Plant Pathology, Physiology and Weed Science, Virginia Polytechnic Institute, Virginia Univ., USA.

Parker, C. and Riches, C.R. (1993) "Parasitic Weeds of the World: Biology and Control”. Cab International, Wallingford, UK, 332p.

Pieterse, A.H. and Verkleij, J.A.C. (1991) Effect of soil conditions on Striga development-a review. Pages 329-339 in: Proceedings of the Fifth International Symposium on Parasitic Weeds.J. K. Ransom, L. J. Mus-selman, A.D. Worsham, and C. Parker, (Ed.). Nairobi, Kenya: CIM-MYT.

Rubiales, D., Sillero, J.C., Román, M.B., Moreno, M.T., Fondevilla, S., Pérez-deLuque, A., Cubero, J.I., Zermane, N., Kharrat, M. and Khalil, S. (2002) Management of broomrape in Mediterranean agriculture. In: "Grain Legumes in the Mediterranean Agriculture. AEP, Ed, Legumed: European Association" for Grain Legume Research, Rabat, Morocco, pp 67-73

Saffour, K., Kharrat, M., Souissi, T., Bouya, D. and Bouhache, M. (2003) Chemical control of Orobanche spp. in faba bean (Vicia faba L.) in the Maghreb. Abstracts Eighth Arab Congress of Plant Protection, $12^{\text {th }}-16^{\text {th }}$ October, El-Beida, Libya,pp.6869.

Schmitt, U.M., Schluter, K. and Boorsma, P.A. (1979) Chemical control of Orobanche crenata in broad beans. FAO. Plant Protection Bulletin, 27, 88-91.

Sauerborn, J., Saxena, M.C. and Mayer, A. (1989) Broomrape control in faba bean (Vicia faba L.) with glyphosate and imazaquin. Weed Res. 29, 97-102.

Thomson, W.T., (1997) “Imazapic. Agricultural Chemicals Book II Herbicides". $13^{\text {th }}$ ed. Fresno, CA: Thomson Publications. pp. 160-161

Westwood, J.H. and Foy, C.L. (1999) Influence of nitrogen on germination and early development of broomrape (Orobanche spp.). Weed Science, 47, 2-7.

Yoneyama, K., Takeuchia, Y. and Yokotab, T. (2001) Production of clover broomrape seed germination stimulants by red clover root requires nitrate but is inhibited by phosphate and ammonium. Physiologia Plantarum, 112, 25-30.

Zahran, M.K., Ibrahim, T., Farag, F.M. and Korollos, M.A. (1980) Chemical control of Orobanche crenata on Vicia faba. FABIS Newsletter, $2,47$.

(Received 26/12/2012;

accepted 28/2/2013) 


\title{
المكافحه المتكامله للهالوك فى الفول البلاى بإستخدام السماد

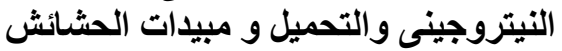

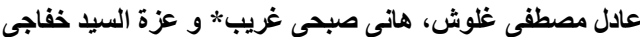

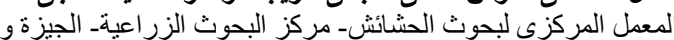

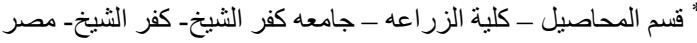

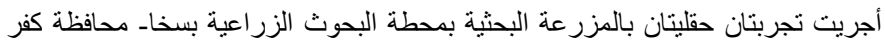

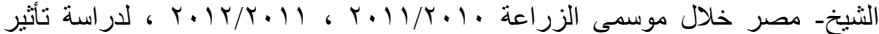

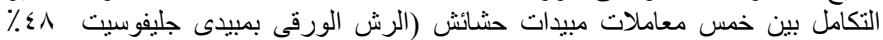

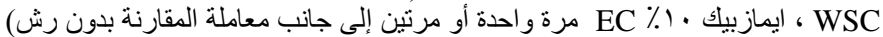

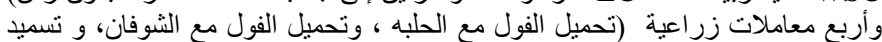

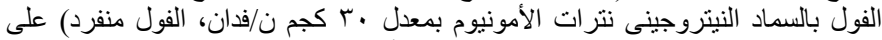

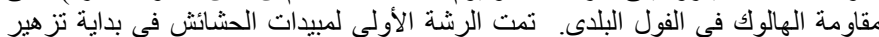

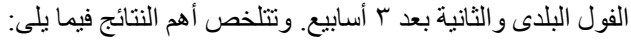

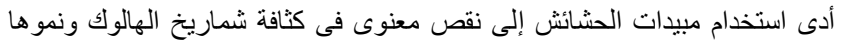

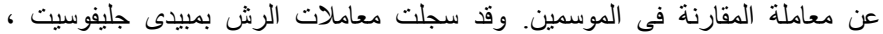

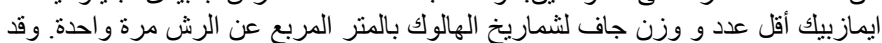

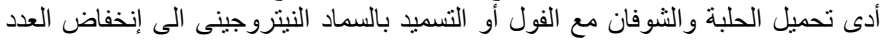

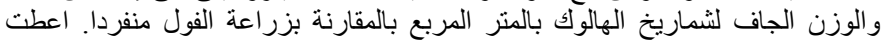

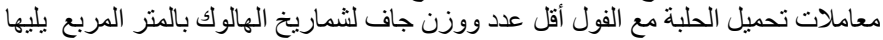

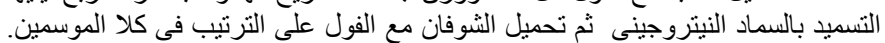

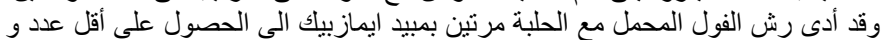

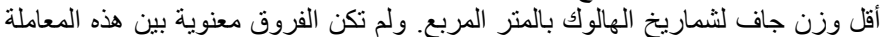

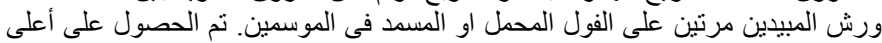

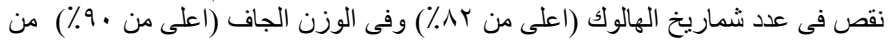
رش الفول المحمل مع الحلبة مرتين بمبيد ايمازبيك في كلا فلا الموسمين.

أدى نكرار رش مبيدات الحشائش الى نقص معنوى فم فى الصبغات النباتية فى أوراق

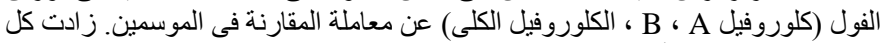

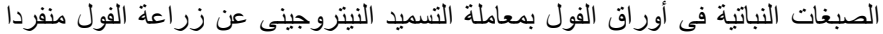
بدون تسميد نتروجينى أو محمل.

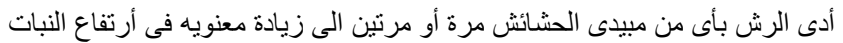

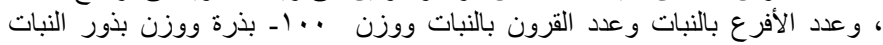

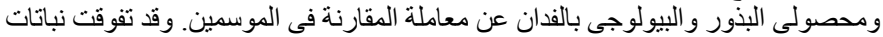

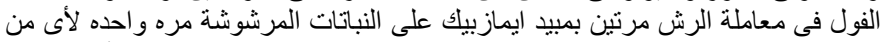

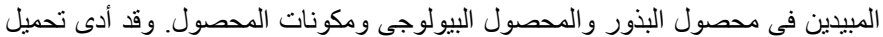

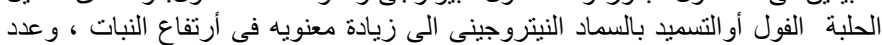

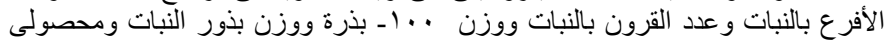

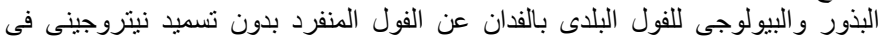

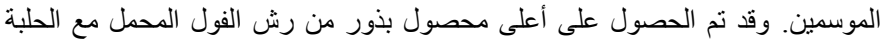

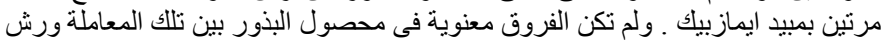
المبيدين مرتين على الفول المحمل او المسمد فى الموسمين.

من نتائج هذا البحث يمكن التوصية بتحميل الحلبة مع الفول أو تسميد الفول بنترات

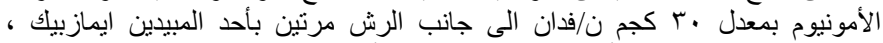

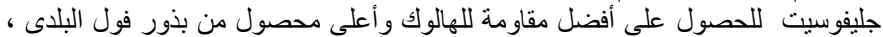
تحت نفس ظروف هذا البحث بمحافظه كفر الثيخ ، مصرك.

Egypt. J. Agron. 34, No. 2 (2012) 